\title{
The Interpretation of Structured, Systematic, and Massive Violations in the 2019 Presidential Election Dispute at the Indonesian Constitutional Court
}

\author{
Heru Widodo ${ }^{1}$ \\ ${ }^{1}$ Faculty of Law, As-Syafi'iyah Islamic University, Jakarta, Indonesia \\ Correspondence: Heru Widodo, Faculty of Law, As-Syafi'iyah Islamic University, Jakarta, Indonesia. E-mail: \\ heruwidodo.fh@uia.ac.id
}

Received: May 29, 2021

Accepted: July 7, $2021 \quad$ Online Published: July 13, 2021

doi:10.5539/jpl.v14n4p47

URL: https://doi.org/10.5539/jpl.v14n4p47

\begin{abstract}
Based on the results of the election of candidates for President and Vice President of the Republic of Indonesia in 2019, an objection was submitted to the Constitutional Court over the results of the vote count by Candidate Pair 02 Prabowo-Sandi. Apart from questioning the correction of miscalculations, objections were also filed against various frauds that caused the candidate's defeat based on structured, systematic, and massive violations. In this article, the problems include: (1) How is the legal aspect of a structured offense, systematic and massive in disputes over election results? (2) What are the law enforcement regulations for election violations and disputes? (3) What is the interpretation of disqualification in the Constitutional Court Decision after the enactment of the Election Law and the Law on General Election of Regional Heads simultaneously? Data analysis used descriptive qualitative, by classifying, comparing, and linking legal materials with the subject matter. The conclusion is various reforms in law enforcement regulations for simultaneous election violations and disputes include the resolution of violations, criminal acts, and election disputes, including the resolution of structured, systematic, and massive violations, accompanied by strengthening of institutions and setting limits on the authority for settlement. In the 2019 Presidential and Vice-Presidential Election, the authority to enforce the law for measurable violations regarding the nomination requirements are submitted to the Election Supervisory Agency and disputed through the State Administrative Court. As for Structured, Systematic, and Massive violations, the reporting process is processed and decided by Bawaslu (Indonesian: Badan Pengawas Pemilu).
\end{abstract}

Keywords: violations, presidential election, dispute, constitutional court, law

\section{Introduction}

Stephen A. Siegel said the problem of counting votes is deep Election is the oldest activity in a nation, among various other problems (Stephen A. Siegel, 2004). Likewise in the Presidential and Vice Presidential Elections, legislative elections, and regional head elections, the vote count results are almost always a problem that is ultimately resolved by the Constitutional Court.

Since amendments to the 1945 Constitution, the constitution provides room for resolution of eligible participants for the arising of vote-counting problems, which have an impact on the electability of participants. About the vote count results of the Presidential and Vice-Presidential Election and the legislative elections, an application may be submitted to the Constitutional Court. As for disputes over vote counting or disputes over the results of regional head elections, there are dynamics of changes in judicial authority. During the first direct regional head elections in 2005, disputes were submitted to the Supreme Court. In 2008, there was a transfer of authority from the Supreme Court to the Constitutional Court, based on Article $236 \mathrm{C}$ of Law Number 12 of 2008 concerning the Second Amendment to the Regional Government Law (Ni'matul Huda, 2011).

The provisions of Article $236 \mathrm{C}$ of Law Number 12 of 2008 concerning the Second Amendment to the Regional Government Law and the provisions of Article 29 paragraph (1) letter e of Law Number 48 of 2009 concerning Judicial Power are submitted for a petition for judicial review to the Constitutional Court. In the Decision of the Constitutional Court Number 97 / PUU-XI / 2013 dated 19 May 2014, it states that the articles regulating the transfer of authority are contrary to the 1945 Constitution, but the Constitutional Court still has the authority to try them until the new regional head election law (Heru Widodo, 2018). 
There are four things that influence changes in electoral politics and electoral laws and regional head elections in Indonesia, namely first, changes to laws; second, President publishes Government Regulation in Lieu of Law (Perppu); Third, the Constitutional Court Decision in reviewing election laws and regional head elections; and fourth, changes to the General Election Commission regulations (Wahyu Nugroho, 2016). Legislative law politics are related to the mechanism for regional head elections, the regulation changes through Law Number 22 of 2014 concerning the Election of Governors, Regents and Mayors and Law Number 23 of 2014 concerning Regional Government, which were originally elected directly to be elected through the Regional People's Representative Council. Regarding the results of the election through the Regional People's Representative Council, the dispute resolution mechanism is not regulated. The regulation takes effect and is revoked on the same day as the issuance of Government Regulation instead of Law Number 1 of 2014 concerning Election of Governors, Regents and Mayors and Government Regulations instead of Law Number 2 of 2014 concerning Amendments to Law Number 23 of 2014 About Local Government.

The material regulated through Government Regulation instead of Law Number 1 of 2014 which was passed became Law Number 1 of 2015 concerning Stipulation of Government Regulation instead of Law Number 1 of 2014 concerning Election of Governors, Regents and Mayors into Law, restoring the mechanism for direct regional head elections. The authority to settle disputes over the results of regional head elections is determined through the High Court and can be submitted for cassation to the Supreme Court. This is stated in Article 157 paragraph (1) of Law Number 1 of 2015, when there is a dispute over the determination of the vote acquisition results of the Election, Election participants can submit a request for cancellation of the determination of the vote count result by the Provincial General Election Commission and Regency / Municipal Election Commission to High Court appointed by the Supreme Court.

The mechanism changed, to be handled by a special judicial body, which was formed before the national concurrent elections. While a special judicial body has not yet been formed, the Constitutional Court is given transitional authority to resolve disputes over the results of simultaneous elections. It is stated in Article 157 paragraph (3) of Law Number 8 of 2015 stipulating that "Cases of disputes over the determination of vote acquisition results are examined and tried by the Constitutional Court until the formation of a special judicial body".

Law Number 1 of 2015 has been amended by Law Number 8 of 2015 dated March 182015 concerning Amendments to Law Number 1 of 2015 concerning Stipulation of Government Regulations instead of Law No.1 of 2014 concerning Election of Governors, Regents and Mayors into Laws. Law Number 8 of 2015 regulates the mechanism for resolving election results disputes through a special judicial body. Article 157 paragraph (1) and (2) of Law Number 8 of 2015 stipulates that cases of disputes over election results are examined and tried by a special judicial body established before the national simultaneous election.

Based on the results of the election for the Candidates for President and Vice President of the Republic of Indonesia in 2019, objections were filed to the Constitutional Court over the vote count results by Candidate Pair 02 PrabowoSandi. Apart from questioning the correction of miscalculations, objections were also filed against various frauds that caused the candidate's defeat based on structured, systematic, and massive violations. The results of the 2019 Presidential Election which is the first product of the simultaneous general election between the Presidential and Vice-Presidential Elections with the legislative elections are interesting to study, considering that Law Number 17 of 2017 concerning General Elections which are conducted simultaneously, has more detail dividing the authority to try violations. and process disputes with disputed election results.

Based on this background, the problems studied can be formulated, namely (1) How are the legal aspects of structured, systematic, and massive violations in disputes over election results? (2) What are the law enforcement regulations for election violations and disputes? (3) What is the interpretation of disqualification in the Constitutional Court Decision after the enactment of the Election Law and the Law on General Election of Regional Heads simultaneously? (4) How is the enforcement of substantive justice after the simultaneous enactment of the General Election Law? and (5) How is the tiered proof of vote acquisition claims?

\section{Research Methods}

This writing includes normative legal research, because the law is conceptualized as what is written in statutory regulations, or law is conceptualized as a rule or norm which is a benchmark for human behavior that is deemed appropriate (Amirudin \& Zainal Asikin, 2004). This research can also be categorized as normative legal research on legal principles (Ronny Hanitijo Soemitro, 1988). This study uses legal literature research, which gets secondary data with materials in the form of books, articles, research results, judicial decisions, laws and regulations, and expert opinions related to the object of research (Soejono Soekanto \& Sri Mamudji, 2007). As normative legal research that focuses on literature law research, secondary data sources are used, consisting of 
primary, secondary, and tertiary legal materials. Data analysis is used as a method of how to use the collected data to solve research problems or as an explanation of the process of utilizing data used to solve problems. Relevant data from library research, processed using qualitative methods. Data relevant to the object of the problem was analyzed descriptively qualitatively. This method uses an inventory of problems in presidential election disputes and juridical analysis of constitutional court decisions, associated with violations that occurred during the presidential election process.

\section{Discussion and Research Results}

\subsection{Legal Aspects of Structured, Systematic, and Massive Offenses}

In 2013, the author researched the preparation of a dissertation with the theme of dispute resolution on the results of post-conflict local elections based on structured, systematic, and massive violations, or in a term well-known in Indonesia abbreviated as "Structured, Systematic, and Massive". In the author's dissertation research at the Constitutional Court in the 2008-2014 period (Heru Widodo, 2017). From this research, it is interesting to point out 3 (three) important aspects of structured, systematic, and massive violation law in that period.

\subsection{Categories of Structured, Systematic, and Massive Offenses}

The dispute over the results of the General Election for the Governor of East Java in 2008 was recorded as a landmark decision by the Constitutional Court which granted the petition based on qualitative violations. In the dispute over the 2004 Presidential and Vice-Presidential Election, arguments for qualitative violations were raised, but the Constitutional Court did not grant them. The categories of violations that can be proven in the dispute over the results of the East Java Regional General Election are Structured, Systematic, and Massive violations, with recalculation and re-voting decisions in several regions. In contrast to the 2008 South Central Timor regional head election dispute, the violation categories used were serious, significant, and structured violations with re-voting orders. In the 2008 North Tapanuli regional head election dispute, it was called a serious and significant violation, while in Kota Tebing Tinggi 2010 it was called a structured, planned, and massive violation, with the decision being re-voted without being followed by related parties. As for the dispute over the election of the West Kotawaringin regional head in 2010 , the categories were structured, systematic, and massive violations with a decision on the disqualification of a candidate pair.

The decision of the Constitutional Court Number 190 / PHPU.D-VII / 2010 in the General Election for Regional Head of Pandeglang Regency, mapped various violations into three categories of violations. First, Structured, Systematic, and Massive violations, which are driven by power or involving officials or administrators, as structured violations that are carried out in a planned or systematic manner, and occur evenly or massively. If it is proven, the verdict can be in the form of recalculation, re-levy, or re-election (Mahrus Ali, et. All, 2012).

Second, a measurable violation. Participants who win the contest, but from the start, do not meet the candidate's requirements (disabled requirements) are categorized as having committed a measured violation, so the participant's disqualification may be decided. The violation occurred in South Bengkulu 2008, a regent candidate who passed the second round was convicted with a sentence of more than five years. Pemilukada (Indonesian: Pemilihan Umum Kepala Daerah) was repeated without being followed by participants with disabilities. In the 2010 Tebing Tinggi City case, the elected mayor was proven to be still serving a suspended sentence. The Constitutional Court ordered a re-vote without a partner with a disability requirement. In addition, also in the 2010 Supiori Regency post-conflict local election.

The decision on the disqualification of a candidate is no longer categorized as a structured, systematic, and massive violation. It is also called a measured violation if there is an obstacle to the right to be a candidate by the organizer. It is categorized as obstruction by the measure that there is a recommendation from the "Panwaslu" (Indonesian: Panitia Pengawas Pemilu) and/or a decision from the State Administrative Court recommending or ordering the inclusion of a prospective pair of candidates. In the 2010 Jayapura City regional head elections, balloons met the requirements, received Panwaslukada recommendations, and pocketed the decision of the State Administrative Court to be included. Because the organizers did not heed "Panwaslukada's" (Indonesian: Panitia Pengawas Pemilihan Umum Kepala Daerah) recommendations and the decisions of the State Administrative Court, the Constitutional Court sentenced them to re-election orders.

Third, sporadic violations, which occurred sporadically that did not significantly affect the electability of candidates. Objections to sporadic violations are decided not accepted or rejected.

\subsection{Justification of Authority to Adjudicate Offenses Structured, Systematic and Massive}

There are 3 (three) reasons to justify the authority of the Constitutional Court in considering violations as part of the dispute over the results at that time. First, as the guardian of the constitution and guardian of democracy, the 
Constitutional Court cannot allow constitutional violations that injure the foundations of democracy and violate election principles. Second, the Constitutional Court decides based on the Indonesian Constitution by the evidence and convictions of the judge. As long as there are violations that are expressly prohibited by the 1945 Constitution, the Constitutional Court, as part of the Electoral Justice System (EJS), is obliged to restore. Recovery is only carried out based on evidence that can convince the judge and is significant. Third, the Constitutional Court guarantees the upholding of democracy and law. In dealing with concrete events, the Constitutional Court does not adjudicate violations but is limited to assessing violations that can be proven to be the cause of winning pairs of candidates.

\subsection{Measures of Significance of Violations Are Structured, Systematic, and Massive}

Not all qualitative violations can be recovered, although in a democracy the principle of "Nemo commodum capere potest de injuria sua propria" applies. There is a measure of significance as a basis for being able to cancel and restore the election results.

The element of significance that is most simply fulfilled is against the measured violation category. Contest winners who do not meet the candidate's requirements from the start, are significant to be repeated. Because, in the case of an election without a candidate who does not meet these requirements, other participants have the potential to win it. Also, in the event of a right to be a candidate, it is significant to be repeated because a candidate who is blocked by the General Election Commission has the potential to win the contestation.

The significant elements in the Structured, Systematic, and Massive violation category are, first: significant if the Structured, Systematic, and Massive violations occur in a place where the applicant loses. Against Structured, Systematic, and Massive violations in areas won by the applicant, it is insignificant. In the event of a violation that was committed by another losing candidate pair (more than two pairs of participants), it is categorized as insignificant. Likewise, if the violation that occurred was both committed by the applicant and the winning candidate pair, it is categorized as insignificant.

The second significant category, in terms of performed recovery, results in changing the configuration of vote acquisition. Third, fulfilling a significant element if there is a condition where law enforcement does not work, or against the operation of law enforcement, the organizer does not respect the decisions of existing law enforcement agencies. Such violations are significant for the Constitutional Court to recover.

\section{Law Enforcement Regulations on Election Violations and Disputes}

The emergence of the findings of the Constitutional Court decision regarding Structured, Systematic, and Massive as the basis for the cancellation of the election results is due to the post-conflict local election regulations which have many deficiencies. Violations and process disputes that arise have not been completely resolved or do not affect candidates who commit violations (Hamdan Zoelva, 2013).

With the renewal of regulations or arrangements in the Act on General Election of Concurrent Regional Heads in 2015 and the Act on Concurrent Elections in 2017, the Constitutional Court decisions in the period for resolving disputes over the results of the 2008-2014 Regional General Elections were used as a source of law formation. Various reforms, including the resolution of violations, criminal acts, and election disputes, including the resolution of structured, systematic, and massive violations, along with strengthening institutions and setting limits on resolution authority (Topo Santoso \& Ida Budhiati, 2018).

In connection with disputes over the results of the 2019 Presidential and Vice-Presidential Election, against measured violations as well as structured, systematic, and massive violations, the authority for law enforcement is regulated at the process dispute stage. Measured violations regarding the nomination requirements submitted to Bawaslu and disputed through the State Administrative Court. Complaints processed and decided by Bawaslu for Structured, Systematic, and Massive Violations. If a participant is disqualified because he is proven to have committed a structured, systematic, and massive violation, he can submit an objection to the Supreme Court, after the General Election Commission issues a decision to cancel as a candidate.

According to the author, the renewal of the arrangement for the settlement of election cases is an open law policy of legislators to build a structure, substance, and ethics and an increasingly mature political culture, with restrictions on the authority to try appointed law enforcement agencies, and limiting the right to participants to "sue". The selection is by the selection stages. Not all restrictions are contrary to the 1945 Constitution. Restrictions are justified according to the Constitution, as long as they guarantee recognition and respect for the rights of freedom of others and to fulfill fair demands based on considerations of moral, religious values, security, and public order. 
The separation between applications for cancellation or disqualification at the nomination stage with disputes over the results of vote acquisition at the post-result stipulation stage in the Election Law constitutes a logical, fair, and legally acceptable limitation that does not mix authority between law enforcement agencies. The rationality of limiting the power to judge between process disputes and outcome disputes is part of an effort to encourage the development of ethics and at the same time an increasingly mature political culture, by formulating norms so that contestants in the Presidential and Vice-Presidential Election do not challenge the election results to the Constitutional Court based on legal issues the institution authorized to do so should have been completed.

\section{Interpretation of Disqualification in the Constitutional Court Decision after the Enactment of the General Election Law and the Law on Concurrent Regional Head Elections}

In the practice of disputes over the results of the Presidential and Vice-Presidential Election as well as the legislative elections, there has been no decision of the Constitutional Court after the enactment of the simultaneous general election law. Therefore, the decision of the Constitutional Court in adjudicating disputes over the results of regional head elections simultaneously since 2015 has been used as a reference to analyze and find out the interpretation of the Constitutional Court regarding the disqualification of candidates submitted in the election result dispute. In the three stages of 2015, 2017 and 2018 simultaneous post-conflict local elections, the interpretation of disqualification can be seen from the Constitutional Court Decision which examines the petition to disqualify participants, a case study of decisions from the three stages of the simultaneous regional head general election.

First, in the case of simultaneous election of Kuantan Singing Regency in 2015, through the Constitutional Court Decision Number 65 / PHP.BUP / 2016, on the request for disqualification of the winning candidate pair because it does not meet the requirements for political party support, according to the Constitutional Court, the legal issue is included in the category of administrative dispute electoral state effort. The mechanism and time limit for resolving these problems have also been clearly and firmly regulated in this law. Thus, the issue of party support requirements that results in the invalid determination of candidate pairs is the authority of other institutions to resolve it.

Second, in a dispute over election results for Jayapura Regency 2017. Regarding the request for disqualification of the 'Petahana' (incumbent) Regent who replaced the official, as recommended by Bawaslu, according to the Constitutional Court, the recommendation was only issued after the recapitulation of the determination of results was completed, so it was not relevant to be considered. The Constitutional Court rejected the request to disqualify.

Regarding disqualification, there was a Constitutional Court decision in the case of PHP in Yapen Islands Regency 2017, which reversed the disqualification action after the election was over. In the quo case, the Petitioner did not meet the $0.5-2 \%$ threshold. One thing or another, because at the plenary meeting of the district-level vote acquisition, the Petitioners' votes were nullified by the Yapen Islands General Election Commission, based on the District Panwaslu's recommendation to disqualify the Petitioners. The General Election Commission of the Republic of Indonesia and the General Election Supervisory Body of the Republic of Indonesia asked the Yapen Islands General Election Commission to revoke the disqualification decision, but this was ignored. Even though it does not meet the threshold requirements, the request is granted with an order to re-vote all polling stations,

Third, in the dispute over the results of the 2018 North Maluku Province general election. The issue of disqualification only emerged at the re-voting stage at the order of the Constitutional Court Interval Judgment. The incumbent governor reportedly violated Article 71 of the law on simultaneous regional head elections. North Maluku Provincial Bawaslu recommended disqualifying the incumbent candidate pairs. Regarding this issue, the Constitutional Court thinks that the settlement of disqualification is the authority of other law enforcement agencies.

The Constitutional Court is consistent in addressing the disqualifications that were only questioned after the voting was over. The settlement of disqualifications in the simultaneous Election regime, based on the views of the Constitutional Court in these decisions, rests with the authority of another institution. Meanwhile, in the event of a disqualification imposed after the election is over, it is restored by the Constitutional Court. These matters, according to the author, are appropriate and relevant to be used as a measure in assessing the request for disqualification in the 2019 Presidential and Vice-Presidential Election dispute.

\section{Enforcement of Substantive Justice after the Enactment of the Concurrent Election Law}

Since qualitative violations in the category of measure as well as structured, systematic, and massive violations in the post-conflict local elections and simultaneous elections were resolved by Bawaslu, does this close the door for the Constitutional Court to uphold substantive justice? Considering that in 2019 there has not been a Constitutional 
Court decision on the disputes over the results of the Concurrent Election, so to find answers, we can study the Constitutional Court decisions in the 2015-2018 simultaneous regional elections on a similar model of legal problems after regulatory reform in the following simultaneous elections and post-conflict local elections.

In the first phase of simultaneous post-conflict local elections in 2015, all applications that did not meet the 0.5$2 \%$ threshold were decided in a dismissal decision without going through a plenary examination of the case. The verdict is unacceptable. There were 7 (seven) cases that met the threshold requirements, but only 4 (four) cases were granted based on repeated violations at polling stations, which were significant for the votes acquired by candidate pairs, not structured, systematic, and massive violations of disputes over results. Selection of Sula Regency, Muna Regency, Bintuni Bay Regency, and Mamberamo Raya Regency in 2015.

In the second phase of simultaneous post-conflict local elections in 2017, there are four decisions of the Constitutional Court that are interesting to observe, because their positions exceed the $0.5-2 \%$ threshold, but were ordered to re-vote. Two of them, the decision on the dispute over the results of the 2017 Puncak Jaya regional head election, although formally it does not meet the threshold, the Constitutional Court is of the view that there are serious violations in the form of not recapitulating the votes acquired by candidate pairs in 6 (six) districts. As for the decision on disputes over the results of the 2017 Tolikara district head general election, the Constitutional Court obtained evidence of the Bawaslu recommendation for re-voting in 18 (eighteen) districts that were not implemented by the General Election Commission. Even though the difference in the votes acquired by the applicant exceeds the threshold.

In the third stage of simultaneous regional head elections in 2018, the progressive interpretation of the Constitutional Court, one of which, refers to the dispute over the results of the 2018 Mimika Regency regional head general election. the threshold requirement is $0.5-2 \%$. Not automatically dismissal the request. There is an essential legal issue that has caught the attention of the Constitutional Court, namely the absence of a Voting Organizer Group Decree from 8 (eight) districts.

The progressiveness of the Constitutional Court, according to the author, is shown in two ways: First, the Constitutional Court did not issue a dismissal decision regarding the threshold but continued the trial to the plenary of proof. The parties were allowed to present witnesses. In the practice of judicial disputes over the results of simultaneous regional head elections in 2015-2017, against applications that do not meet the threshold, dismissal decisions are handed down without examining witnesses. Second, related to the evidence. The Constitutional Court requested that the copy of documentary evidence be matched one by one, about various Decrees on the Appointment of Voting Organizers in 8 (eight) districts which the Petitioner argued did not have a Decree.

From these decisions, the Constitutional Court has not lost its progress in upholding substantive justice. About the case of 2019 Presidential and Vice-Presidential Election, granting the authority to try structured, systematic and massive violations to Bawaslu and administrative disputes and administrative disputes of the Electoral State to the State Administrative Court, does not make the Constitutional Court a "Calculator Court" which only puts forward procedural justice. As for the request to disqualify a new pair of candidates submitted after the election is over and the winner is known, there is not sufficient reason to combine cases between cases that fall under the authority of Bawaslu and/or the authority of Peratun to resolve them with cases of dispute over results, in one case before the Constitutional Court. Moreover, the problem of Structured, Systematic, and Massive violations has been submitted to Bawaslu and there is a Bawaslu decision on the matter.

\section{Tiered Proof of Claims of Voting Claims}

About quantitative issues, the notes that can be conveyed are about the corrections to the correct vote acquisition results according to the Constitutional Court. Corrections can be immediately determined based on the evidence juxtaposed between the applicant's version and the respondent's version. Correction can also be preceded by a recount or re-voting, which depends on evidence at the trial.

By the prevailing principle of proof, who is arguing, he is the one who proves it. Thus, a heavy burden rests on the applicant's shoulders to prove the truth of his version of the vote claim. First, the applicant must be able to indicate the source of these figures. Of course, if there are differences at the provincial level, at least the claimant's vote acquisition claim will be backed up or strengthened by evidence of the results of the lower level recapitulation in the district/city. If there are still doubts, strengthening can be done with evidence of the DA-1 Kecamatan model form in all provinces which are claimed to be different. Evidence that has evidentiary value is an official document from the organizer according to the level. This is the first ladder to convince the judge of the correct correction according to the Constitutional Court. 
Second, the applicant's version of evidence still has to be contested with the competing evidence of the respondent, Bawaslu, and/or related parties. Contesting evidence or comparing material evidence from the parties is the second ladder to make correct corrections according to the Constitutional Court. The third ladder, a matter of significance. After the document authentication questions are fulfilled, and the comparison questions are found to be miscalculated, the correction still has to go through a significant scale. Whether this miscalculation, after the corrections are added up, the result changes the candidate pair's electability configuration, or not. If there is a calculation error or difference in the calculation, but the final result does not change the configuration of the candidate pair's electability, the reasons for the application are not proven and lead to the application being rejected.

\section{Conclusion}

Structured, Systematic, and Massive Violations are qualitative violations that originally used several terms, including serious, significant, and structured violations, structured, planned, and massive violations. Three categories of qualitative violations: (1) Structured, Systematic, and Massive violations, (2) measurable violations, and (3) sporadic violations. There are two measures of significance as the basis for canceling and restoring the election results: (1) in measured violations, the winner of the contest from the start does not qualify for the candidate, significant to be repeated. In the case of an election without a candidate who does not meet the requirements, the other participants have the potential to win. In the event of a deprivation of the right to vote, it is significant that it is repeated, because the candidate who is blocked has the potential to win. (2) Significant elements in structured, systematic, and Massive (a): significant if the violation occurs at the place where the applicant loses. The violations in the territory won by the applicant were insignificant. The violations committed by the other losing candidate pairs were insignificant. The violations committed by both the applicant and the winning candidate pair were insignificant. (b) Significant if the recovery is carried out, the results will change the configuration of the participant's vote. (c) Significant if there is a condition where law enforcement does not work, or against the operation of law enforcement, the decision of the law enforcement agency is not respected. In the 2019 Presidential and Vice-Presidential Election, the authority to enforce the law for measurable violations regarding the nomination requirements are submitted to the Election Supervisory Agency and disputed through the State Administrative Court. As for Structured, Systematic, and Massive violations, the reporting process is processed and decided by "Bawaslu". If a participant is disqualified because he is proven to have committed a structured, systematic, and massive violation, he can submit an objection to the Supreme Court. Interpretation of disqualification in the Constitutional Court Decision after the enactment of the Law on Concurrent General Elections and the Law on General Election of Regional Heads refers to the decision of the Constitutional Court in disputes over the results of the simultaneous post-conflict local elections since 2015.

\section{Reference}

Ali, M., et. al. (2012) Tafsir Konstitusional Pelanggaran Pemilukada yang Bersifat Sistematis, Terstruktur, dan Masif, Jurnal Konstitusi, 9(1).

Amirudin, \& Asikin, Z. (2004). Pengantar Metode Penelitian Hukum. Jakarta: Raja Grafindo Persada.

Constitutional Court Decision Number 190 / PHPU.D-VII / 2010.

Constitutional Court Decision Number 65 / PHP.BUP / 2016.

Huda, N. (2011). Dinamika Ketatanegaraan Indonesia dalam Putusan Mahkamah Konstitusi. Yogyakarta: Fakultas Hukum Universitas Islam Indonesia Press.

Law of the Republic of Indonesia Number 1 of 2015 concerning the Election of Governors, Regents, and Mayors.

Law of the Republic of Indonesia Number 10 of 2016 concerning the Second Amendment to Law Number 1 of 2015 concerning Stipulation of Government Regulations instead of Law Number 1 of 2014 concerning Election of Governors, Regents, and Mayors Into Laws.

Law of the Republic of Indonesia Number 12 of 2008 concerning Second Amendment to Law Number 32 of 2004 concerning Regional Government.

Law of the Republic of Indonesia Number 17 of 2017 concerning General Elections.

Law of the Republic of Indonesia Number 22 of 2014 concerning the Election of Governors, Regents, and Mayors.

Law of the Republic of Indonesia Number 23 of 2014 concerning Regional Government.

Law of the Republic of Indonesia Number 24 of 2003 concerning the Constitutional Court.

Law of the Republic of Indonesia Number 48 of 2009 concerning Judicial Power. 
Law of the Republic of Indonesia Number 8 of 2011 concerning Amendments to Law Number 24 of 2003 concerning the Constitutional Court.

Law of the Republic of Indonesia Number 8 of 2015 dated March 182015 concerning Amendments to Law Number 1 of 2015 concerning Stipulation of Government Regulations instead of Law Number 1 of 2014 concerning Election of Governors, Regents, and Mayors into Law.

Nugroho, W. (2016). Politik Hukum Pasca Putusan Mahkamah Konstitusi atas Pelaksanaan Pemilu dan Pemilukada di Indonesia. Jurnal Konstitusi, 13(3). https://doi.org/10.31078/jk1331

Peraturan Pemerintah Pengganti Undang-Undang Nomor 1 Tahun 2014 tentang Pemilihan Gubernur, Bupati, dan Walikota.

Santoso, T., \& Budhiati, I. (2018). Pemilu di Indonesia Kelembagaan, Pelaksanaan, dan Pengawasan. Jakarta: Sinar Grafika.

Siegel, S. A. (2004). The Conscientious Congressman's Guide to The Electoral Count Act of 1887. Florida Law Review.

Soekanto, S., \& Mamudji, S. (2007). Metodologi Penelitian Hukum Normatif Suatu Tinjauan Umum. Jakarta: Raja Grafindo Persada.

Soemitro, R. H. (1988). Metodologi Penelitian Hukum dan Jurimetri. Jakarta: Ghalia Indonesia.

Suriasumantri, J. S. (1986). Ilmu dalam Perspektif Moral, Sosial dan Politik:Sebuah Dialog tentang Kelimuan Dewasa ini. Jakarta: Gramedia.

The 1945 Constitution of the Republic of Indonesia.

Widodo, H. (2017). Penyelesaian Sengketa Hasil Pemilukada: Evaluasi Terhadap Prosedur Beracara di Mahkamah Konstitusi Indonesia 2008-2014. Disertasi pada Fakultas Hukum Univesitas Padjadjaran, Bandung.

Widodo, H. (2018). Hukum Acara Sengketa Pemilukada, Dinamika di Mahkamah Konstitusi. Jakarta: Konpress.

Zoelva, H. (2013). Problematika Penyelesaian Sengketa Hasil Pemilukada oleh Mahkamah Konstitusi. Jurnal Konstitusi, 10(3).

\section{Copyrights}

Copyright for this article is retained by the author(s), with first publication rights granted to the journal.

This is an open-access article distributed under the terms and conditions of the Creative Commons Attribution license (http://creativecommons.org/licenses/by/4.0/). 